\title{
An Econometric Assessment of the Impact of Exchange Rate Depreciation on Inflation in Nigeria (1981-2017).
}

\author{
*Apeh Kenneth, Abubakar Muhammad Auwal, Nweze Obini \\ Nwanze. \\ Department of Statistics, Nasarawa State University, Keffi, Nasarawa State, Nigeria \\ *Corresponding Authors:apehken@gmail.com;abalkafawi1 @ nsuk.edu.ng; \\ obininweze@yahoo.com +2347031209203
}

\begin{abstract}
The present reality of the Nigerian economy is the fact that inflation has remained unabated in spite of all exchange rate measures that have been adopted by the monetary authority. This calls for investigation into the extent to which exchange rate impact on inflation in Nigeria. The research paper examined the impact of exchange rate depreciation on inflation in Nigeria for the period 1981-2017, using Auto Regressive Distributed Lag (ARDL) Bounds Test Cointegration Procedure. The research shows that inflation rate in Nigeria is highly susceptible to lagged inflation rate, exchange rate, lagged exchange rate, lagged broad money, and lagged gross domestic product at 5\% level of significance. A long run relationship was also found to exist between inflation rate, gross domestic product and general government expenditure, indicating that the model has a self-adjusting mechanism for correcting any deviation of the variables from equilibrium. Therefore, this study concludes that exchange rate is an important tool to manage inflation in the country; thus, this paper recommends that policies that have direct influence on inflation as well as exchange rate policies that would checkmate inflation movement in the country, should be used by the Central Bank of Nigeria. Also, monetary growth and import management policies should be put in place to encourage domestic production of export commodities, which are currently short-supplied. In addition, policy makers should not rely on this instrument totally to control inflation, but should use it as a complement to other macro-economic policies.
\end{abstract}

Keywords: Exchange rate, Inflation rate; Gross Domestic Product, Broad Money, Monetary Policy, ARDL Cointegration.

\subsection{Introduction}

The two important elements for measuring macroeconomic performance of a country are inflation and exchange rate. Fluctuations in the economic growth are caused by foreign exchange and increase in prices of goods and services. The major 
source of concern in all countries since 1970s is the volatility of the nature of prices. This problem is more serious in the developing countries where inflation in foreign countries known as "imported inflation" is seen to be driving "domestic inflation"; making it difficult for domestic policies to control inflation. Mainly, the inflation rate is used to measure the price stability in the economy. It can be divided into two sides, namely: demand side inflation and supply side inflation. Generally, inflation affects different people or economic agents differently. Broadly, there are two economic groups in every society, the flexible income and the fixed income group. During inflation, those in the former group gain while those in the latter group lose. This is because the price movement of different goods and services are not uniform.

The influence of exchange rate towards inflation itself depends on the choice of exchange rate regime in the country. Exchange rate system has an important role in minimizing the risk of fluctuations in exchange rates. Any changes in exchange rates will have a great impact on the economy. In the system of floating exchange rates, exchange rate fluctuations can have a strong impact on the level of prices through the aggregate demand and aggregate supply. On the aggregate supply, depreciation (devaluation) of domestic currency can affect the price level directly through imported goods that domestic consumers pay. The declining of exchange rate will cause the price of inputs more expensive, thus leading to a higher cost of production. Manufacturers will in turn increase the cost to the price of goods that will be paid by consumers. As a result, the price level aggregate in the country increases and if it persists, it will lead to inflation.

This study examined the impact of exchange rate on inflation in Nigeria in the face of other macroeconomic indicators and also determines the relationship existing between them.

\subsection{Review of Literature}

This research work will be based on some empirical studies to enable a complete investigation of the exchange rate impact on inflation in Nigeria. According to Imimole and Enoma (2011), who examined the impact of exchange rate depreciation on inflation in Nigeria for the period 1986-2008, using Auto Regressive Distributed Lag (ARDL) Cointegration Procedure. The research found that exchange rate depreciation, money supply and real gross domestic product are the main determinants of inflation in Nigeria, and that Naira depreciation is positive, and has significant long-run effect on inflation in Nigeria. This implies that exchange rate depreciation can bring about an increase in inflation rate in Nigeria. The paper also found that inflationary rate in Nigeria has a lagged cumulative effect.

In the same vein, Nwaru \& Eke (2017) also examined the effect of exchange rate on inflation in Nigeria using annual data from 1970 to 2014; their main objective is to investigate the extent to which exchange rate impact on inflation in Nigeria. Consequently, their findings show that inflation was responsive to lagged inflation, exchange rate, money supply and import prices in Nigeria. 
Also Emerenini, \& Eke (2014) investigated the determinants of inflation in Nigeria using a monthly data from January 2007 to August 2014. The ordinary least square (OLS) method was adopted. The result showed that expected inflation, exchange rate and money supply influenced inflation, while annual treasury bill rate and monetary policy rate though rightly signed did not influence inflation in Nigeria within the period under investigation.

Ude \& Anochie (2014) investigated the impact of exchange rate pass-through on monetary policy and price stability in Nigeria using quarterly data from 1986:1 through 2012:4 using multi-linear regression models. Results show that there is complete exchange rate pass-through response with selected monetary policy variables except for interest rate. However, incomplete exchange rate pass-through was found with price stability in Nigeria.

Hunegnaw (2012) investigated the foreign exchange pass to domestic price in Ethiopia for the year 1981 to 2013 using Auto Regressive Distributed Lag (ARDL) cointegration procedure. The result shows that foreign exchange pass to domestic price is not significant. Broad money supply, budget deficit and world commodity price index are the main determinates of domestic consumer price in Ethiopia.

\subsection{Materials and Methods}

The method used by this study was autoregressive distributed lag (ARDL) bound testing procedure developed by Pesaran et al (2001) to examine the cointegration or long-run relationship between inflation and exchange rate in Nigeria. The choice of this test is based on the following considerations. Firstly, the ARDL cointegration technique is adopted irrespective of whether the underlying variables are $\mathrm{I}(0), \mathrm{I}(1)$ or a combination of both, and cannot be applied when the underlying variables are integrated of order I(2). Thus, to avoid cashing of the ARDL technique, it is advisable to test for unit roots since variables that are integration of I (2) leads to the crashing of the technique. Secondly, if the F-statistics (Wald test) establishes that there is a single long run relationship and the sample data size is small $(\mathrm{n} \leq 30)$ or finite, the ARDL error correction representation becomes relatively more efficient. According to Pesaran et al (2001), to apply the bounds test procedure, a conditional Vector Error Correction Model (VECM) of interest can be specified to test the cointegration relationship between the underlying variables.

The econometric tools that were used for these verifications are the Augmented Dickey-Fuller test for stationarity, Johansen co-integration test for long term relationship and diagnostic tests of the underlying variables. The stability of the estimated model was verified using the CUSUM and CUSUMSQ stability tests. This research work the effect of exchange rate on inflation in Nigeria was investigated using a secondary data. The data used in this study are time series annual data spanning from 1981 to 2017. These data were sourced from the World Bank website (www.worldbank.org). The datasets was transformed using natural log to ensure normality, stability and to reduce skewness and kurtosis. These time series data include; Inflation Rate (INF), Exchange Rate (EXC), Broad Money (BM), Real Gross Domestic Product (GDP) and General Government Expenditure (GGEXP). 


\subsection{Model Formulation}

\subsection{The Long-Run Model}

To establish the long-run impact of exchange rate on inflation, the ordinary least square method was applied through a multiple regression model.

Therefore, the functional model for this study is:

$$
I N F=f\left(E X C, G D P, B M, G G E X P, I N F_{t-1}\right)
$$

Where;

$$
\begin{aligned}
& \text { INF = Inflation Rate, } \\
& \text { EXC = Exchange Rate, } \\
& \text { GDP = Gross Domestic Product, } \\
& \text { BM = Broad Money, } \\
& \text { GGEXP = General Government Expenditure } \\
& \text { INF-1 = Expected (lagged) Inflation Rate. }
\end{aligned}
$$

From equation 1a, Inflation depends on exchange rate, GDP, broad money, general government expenditure and lagged inflation. Therefore, the inflation function for Nigeria as it relates to this investigation may be specified in log linear form as follows.

$$
\begin{aligned}
& \operatorname{LnINF}_{t}=\beta_{0}+\beta_{1} \operatorname{LnINF}_{t-1}+\beta_{2} L n E X C_{t}+\beta_{3} L n G D P_{t}+\beta_{4} \operatorname{LnBM} t
\end{aligned}
$$

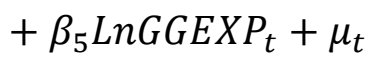

Where;

$\operatorname{LnINF}_{t}=$ Inflation Rate in the Current Period

$\operatorname{LnINF}_{t-1}=$ One Year Lagged Inflation Rate

$L n E X C_{t}=$ Exchange Rate of the Naira in Terms of US Dollar in period t.

$\operatorname{LnGDP}_{t}=$ GDP Per Capita in the Current Period

$\operatorname{LnB} M_{t} \mathrm{t}=$ Broad Money in period $\mathrm{t}$

LnGGEXP $P_{t}=$ General Government Expenditure in the Current Period

$\mu_{t}=N I D\left(0, \sigma^{2} \varepsilon\right)$ denoting an independent $(\mathrm{I})$, normal $(\mathrm{N})$ distribution with a mean of zero $\left(E\left(\varepsilon_{t}\right)=0\right)$ and a variance $\left(V\left(\varepsilon_{t}\right)=\sigma^{2} \varepsilon\right)$; since these are constant parameters, an identical distribution holds at every point in time.

\subsection{The Autoregressive Distributed Lag (ARDL)}

The Autoregressive Distributed Lag (ARDL) version of equation (1b) model is expressed as follows: 


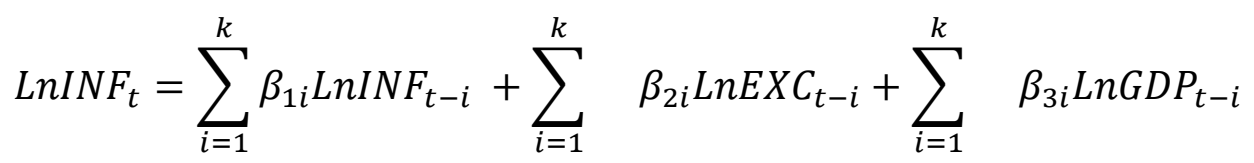

$$
\begin{aligned}
& +\sum_{i=1}^{k} \beta_{4 i} \operatorname{LnBM}_{t-i}+\sum_{i=1}^{k} \beta_{5 i} \operatorname{LnGGEXP_{t-i}} \\
& +\mu_{t}
\end{aligned}
$$

The primary aim of the study is to estimate the long run relationship between inflation and exchange rate depreciation. The correct specification of such a long-run relationship that will capture the short-run deviations that might have occurred in estimating the long-run cointegrating equation requires an error correction term (Onwioduokit 2000 and Osakwe 1983)

\subsection{The Error Correction Model}

Following Pesaran et al (2001) the error correction representation of the above ARDL model (2) is given by

$$
\begin{aligned}
& \Delta L n I N F_{t}=\beta_{0}+\sum_{i=1}^{k} \beta_{1 i} \Delta L n I N F_{t-i}+\sum_{i=1}^{k} \beta_{2 i} \Delta L n E X C_{t-i} \\
& +\sum_{i=1}^{k} \beta_{3 i} \Delta L n G D P_{t-i}+\sum_{i=1}^{k} \beta_{4 i} \Delta L n B M_{t-i} \\
& +\sum_{i=1}^{k} \beta_{5 i} \Delta L n G G E X P_{t-i}+\delta_{1} L_{n I N F_{t-1}}+\delta_{2} L n E X C_{t}+\delta_{3} L n G D P_{t} \\
& +\delta_{4} L n B M_{t}+\delta_{5} L n G G E X P_{t} \\
& +\mu_{t}
\end{aligned}
$$

Where, the parameters $\beta_{i}: \mathrm{i}=1,2,3,4,5$ are the short-run dynamic coefficients, while the parameters $\delta_{i}: \mathrm{i}=1,2,3,4,5$ function as the long-run multipliers of the underlying ARDL model.

Theoretically, it is expected that

$\beta_{1}>0 ; \beta_{2}>0 ; \beta_{3}<0 ; \beta_{4}>0 ; \beta_{5}>0$

This means that with the exception of real GDP, all coefficients on the variables are expected to have positive signs.

\subsection{Results and Discussions}

\subsection{Trend Movement}


In fig 1 below, it is observed that there is fluctuation in Exchange Rate, General Government Expenditure and Inflation Rate while Gross Domestic Product and Broad Money are stable.

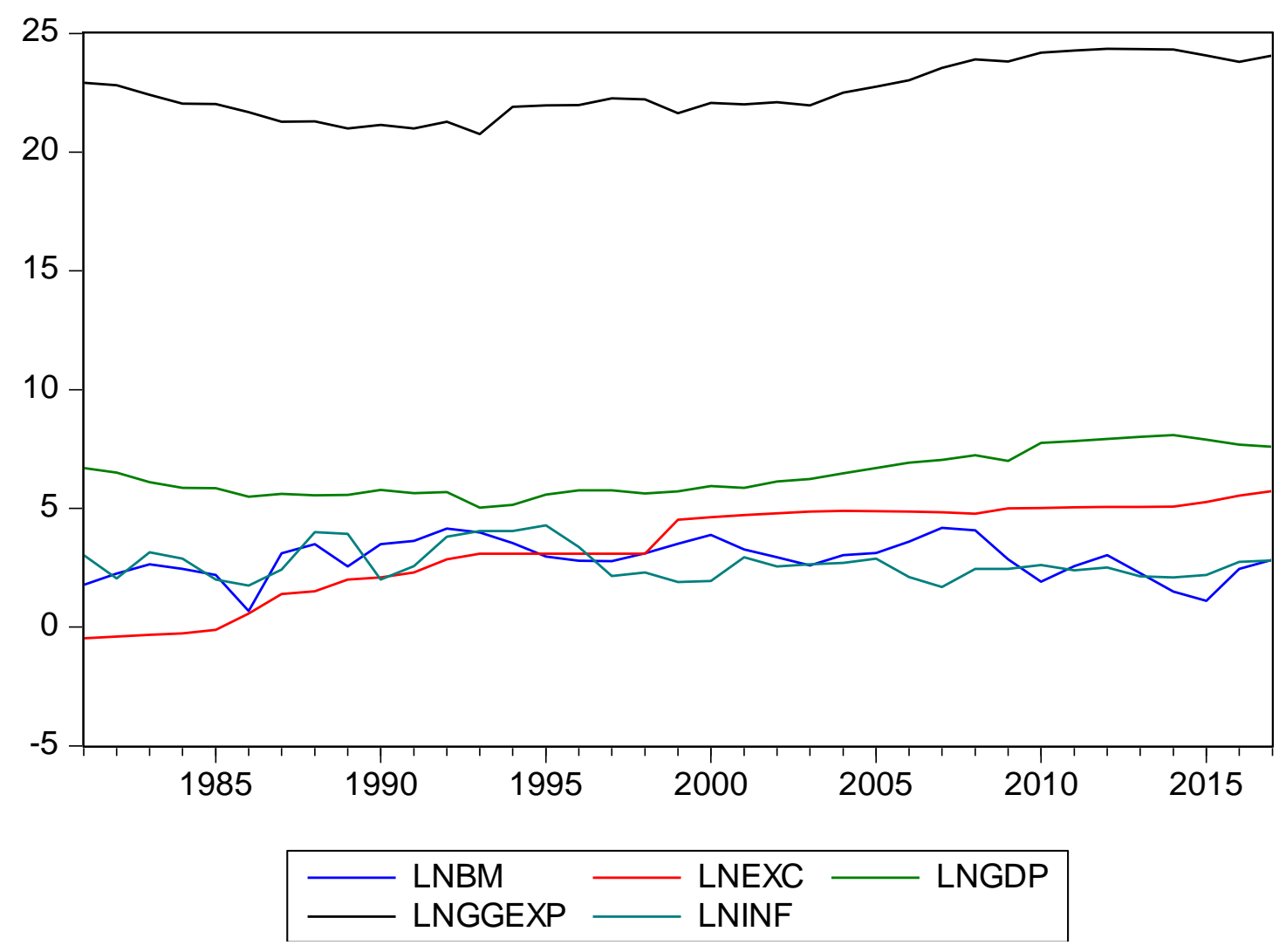

Fig. 1. Trend Movement of Inflation Rate, GDP, Broad Money, General Government Expenditure, and Exchange Rate in Nigeria from 1981 - 2017.

Source: Author's computation and Eviews 9.0 Output

\subsection{Unit Roots Tests}

Before we perform the ARDL bounds test, we need to test for the stationarity status of all variables to determine their order of integration. This is to ensure that the variables are not stationary at order 2 so as to avoid spurious results. According to Ouattara (2004) in the presence of I(2) variables the computed F-statistics provided by Pesaran et al. (2001) are not valid because the bounds test is based on the assumption that the variables are $\mathrm{I}(0)$ or $\mathrm{I}(1)$. Therefore, the implementation of unit root tests in the ARDL procedure is necessary in order to ensure that none of the variables is integrated of order 2 or beyond. The tests were run with intercept and linear trend. The Mckinnon critical values at $5 \% \mathrm{t}$ level of significance were obtained as -2.945842 and -2.948404 in levels and in first difference respectively. Table 1 present the results of the ADF test in levels and in first difference, for all the variables. 
Table 1: ADF Unit Root Test (ADF Regression with Intercept and a Linear Trend).

\begin{tabular}{|c|c|c|c|}
\hline Variables & $\begin{array}{c}\text { Order of } \\
\text { Integration }\end{array}$ & T-Statistics ADF & $\begin{array}{c}\text { Critical } \\
\text { ADF Statistics }\end{array}$ \\
\hline LnINF & $\mathrm{I}(0)$ & -3.298617 & -2.945842 at $5 \%$ \\
\hline LnGDP & $\mathrm{I}(1)$ & -5.344071 & -2.948404 at $5 \%$ \\
\hline LnBM & $\mathrm{I}(0)$ & -3.278260 & -2.945842 at $5 \%$ \\
\hline LnGGEXP & $\mathrm{I}(1)$ & -6.213766 & -2.948404 at $5 \%$ \\
\hline LnEXC & $\mathrm{I}(1)$ & -5.113505 & -2.948404 at $5 \%$ \\
\hline
\end{tabular}

Source: Author's computation and Eviews 9.0 Output

Table 1 shows the ADF test statistics for all the variables. The table shows that all the variables are integrated either at levels or at the first difference, $\mathrm{I}(0)$ or $\mathrm{I}(1)$. This implies that we can boldly apply the ARDL methodology for our model. The computed F-statistics of the bounds test is reported in Table 2 below.

\subsection{Bounds Test}

From Table 2 below, we see that the F-statistic for the Bounds Test is 6.35, and this clearly exceeds the $5 \%$ critical value for the upper bound 4.01.Accordingly, we strongly reject the null hypothesis of no long-run relationship, implying that long-run cointegration relationships amongst the variables exist.

Table 2: Results from ARDL Bounds Test

\begin{tabular}{lcc}
\hline Null Hypothesis: No long-run relationships exist & \\
\hline Test Statistic & Value & $\mathrm{k}$ \\
F-statistic & 6.352576 & 4 \\
\hline
\end{tabular}

Critical Value Bounds

\begin{tabular}{ccc}
\hline Significance & I0 Bound & I1 Bound \\
\hline $10 \%$ & 2.45 & 3.52 \\
$5 \%$ & 2.86 & 4.01 \\
$2.5 \%$ & 3.25 & 4.49 \\
$1 \%$ & 3.74 & 5.06 \\
\hline
\end{tabular}

Source: Author's computation and Eviews 9.0 Output

\subsection{Estimated Long Run Coefficients}

The estimated long run result in Table 3 shows that in the long run Gross Domestic Product (GDP) and General Government Expenditure (GGEXP) have very significant 
effect on inflation, though general government expenditure has a negative influence on inflation. The result also shows that Exchange Rate (EXC) is negatively insignificant with inflation rate with a coefficient and p-value of $(-0.115622$ and 0.3731 ) respectively while Broad Money (BM) is also insignificant but in a positive way, it has a coefficient and p-value of (0.641380 and 0.2472) respectively. This means that $10 \%$ increase in EXC and BM will lead to 11.56 and 64.13 percent increase in inflation rate respectively.

Table 3: Estimated Long Run Coefficients using the ARDL Approach

Dependent Variable: LnINF

\begin{tabular}{cccccc}
\hline Variable & Coefficient & Std. Error & t-Statistic & Prob. & Remarks \\
\hline LnGDP & 2.071256 & 0.802804 & 2.580027 & 0.0274 & Significant \\
LnBM & 0.641380 & 0.521852 & 1.229046 & 0.2472 & Not Significant \\
LnGGEXP & -1.698719 & 0.572483 & -2.967284 & 0.0141 & Significant \\
LnEXC & -0.115622 & 0.123995 & -0.932468 & 0.3731 & Not Significant \\
C & 26.252938 & 8.343078 & 3.146673 & 0.0104 & \\
\hline
\end{tabular}

Source: Author's computation and Eviews 9.0 Output

\subsection{Error Correction Model (ECM) Representation}

An examination of the estimated result below shows that the overall fit of the model is acceptable at the value of $\mathrm{R}^{2}=0.946131$. This shows that the independent variables used in our model jointly accounted for $94.6 \%$ of the total variation in inflation rate. The P-values of $0.056,0.039,0.015,0.045$ and 0.039 indicates that five of the explanatory variables are highly significant (at $5 \%$ level) in explaining inflation in Nigeria, except general government expenditure with P-value of 0.096. Also, one lagged value of inflation is found to be positively significant in explaining inflation in Nigeria at 5\% level of significance. This implies that inflation has a cumulative effect in Nigeria; in fact, a unit increase in inflation in one year will increase inflation in the subsequent year by $32.2 \%$ likewise, two lagged values of exchange rate is found to be positively significant in explaining inflation in Nigeria at $5 \%$ level of significance, which implies that a unit increase in exchange rate in two years will increase inflation in the subsequent year by $76.1 \%$. This shows that inflation in Nigeria is highly responsive to changes in exchange rate depreciation, broad money and real GDP. It also implies that exchange rate depreciation, money supply and real GDP are major determinants of inflation in Nigeria.

The coefficient of the ECM is negative, and highly significant, showing that the model has a self-adjusting mechanism for adjusting the short-run dynamics of the variables with their long-run values. According to (Afolabi, 1995), a highly significant error correction term is a further proof of the existence of a stable long run relationship. This implies that there is a long-run relationship between inflation and its determinants. The speed of adjustment to equilibrium is given by the coefficient of ECM (-1) as -0.64 . This speed is high, indicating that a deviation in inflation rate from 
equilibrium is corrected by as high as $64 \%$ the following year. The F-statistic of 7.983440 is significant at $5 \%$ level, as the P-value estimate of 0.0009 has indicated. It shows that there is a linear relationship between the dependent variable and at least one of the independent variables. Thus, it will rightly act to correct any deviations from long-run equilibrium. The Durbin Watson statistics of 2.56080 indicates that there is absence of serial autocorrelation. This implies that the statistical estimates can be relied upon.

Table 4: Error Correction Model Representation for the Selected ARDL Model

Dependent Variable: LnINF

Method: ARDL

Sample (adjusted): 1985 - 2017

Model selection method: Akaike info criterion (AIC)

Dynamic regressors (4 lags, automatic): LnGDP LnBM LnGGEXP LnEXC

Selected Model: ARDL $(3,4,4,4,3)$

\begin{tabular}{|c|c|c|c|c|c|}
\hline Variable & Coefficient & \multicolumn{2}{|c|}{ Std. Error } & t-Statistic & Prob. \\
\hline $\mathrm{D}(\operatorname{LnINF}(-1))$ & 0.322430 & \multicolumn{2}{|c|}{0.149242} & 2.160443 & 0.0561 \\
\hline $\mathrm{D}(\operatorname{LnGDP}(-1))$ & -1.109292 & \multicolumn{2}{|l|}{0.467181} & -2.374439 & 0.0390 \\
\hline $\mathrm{D}(\operatorname{LnBM}(-3))$ & -0.419398 & \multicolumn{2}{|l|}{0.142887} & -2.935176 & 0.0149 \\
\hline D(LnGGEXP) & -0.675049 & \multicolumn{2}{|l|}{0.366849} & -1.840127 & 0.0956 \\
\hline $\mathrm{D}(\operatorname{LnEXC})$ & -0.864600 & \multicolumn{2}{|c|}{0.376781} & -2.294701 & 0.0447 \\
\hline $\mathrm{D}(\operatorname{LnEXC}(-2))$ & 0.761017 & \multicolumn{2}{|l|}{0.321621} & 2.366193 & 0.0395 \\
\hline $\mathrm{C}$ & 16.79085 & \multicolumn{2}{|c|}{5.739833} & 2.925320 & 0.0152 \\
\hline $\operatorname{ECM}(-1)$ & -0.639580 & \multicolumn{2}{|l|}{0.186910} & -3.421856 & 0.0065 \\
\hline \multicolumn{6}{|c|}{$\begin{array}{l}\mathrm{ECM}=\mathrm{LnINF}-(2.0713 * \operatorname{LnGDP}+0.6414 * \operatorname{LnBM}-1.6987 * \operatorname{LnGGEXP} \\
-0.1156 * \operatorname{LnEXC}+26.2529)\end{array}$} \\
\hline R-squared & \multicolumn{2}{|c|}{$=0.946131$} & & ljusted R-squared & $=0.827619$ \\
\hline S.E. of regression & \multicolumn{2}{|l|}{$=0.306019$} & & m squared resid & $=0.936479$ \\
\hline $\mathbf{F}(7,33)$ & \multicolumn{2}{|c|}{$=7.983440[0.000863]$} & & aike info criterion & $=0.669681$ \\
\hline Durbin-Watson stat & \multicolumn{2}{|c|}{$=2.56080$} & & hwarz criterion & $=1.712701$ \\
\hline
\end{tabular}

Source: Extracted from Regression Output using Eviews 9.0

\subsection{Diagnostic Test}

From Table 5 below, the test of serial correlation was carried out on the model; the result revealed that there is no serial correlation, since the (Prob- Value $=0.5147 \mathrm{>}$ 0.05). The implication is that the inflation rate model is good for forecasting. The test of Heteroskedasticity test was carried out on the model, the result revealed that the variance of the residual is constant, since the (Prob-Value $=0.9144>0.05$ ). Jarque-Bera test is a test of normality, since the (Prob-Value $=0.9871>0.05$ ). We conclude that population is normally distributed.

Table 5: Results of diagnostic tests

\begin{tabular}{lcc}
\hline & $\boldsymbol{X}^{2}$-statistic & Probability \\
\hline Breusch-Godfrey Serial Correlation LM Test & 0.722487 & 0.5147 \\
Heteroskedasticity Test: Breusch-Pagan-Godfrey & 0.502097 & 0.9144 \\
Jarque-Bera test & 0.025895 & 0.9871 \\
\hline
\end{tabular}


Source: Author's computation and Eviews 9.0 Output

\subsection{Test of Stability for the Long-Run Model}

The cumulative sum of recursive residuals (CUSUM) and the CUSUM of square (CUSUMSQ) tests are used to evaluate the stability of the model when applied on the residuals. It is expected that both CUSUM and CUSUMSQ plots should be within the critical bounds at 5\% significant level for the model to be accepted as being stable. From Fig. 2 and Fig. 3, both the CUSUM and CUSUMSQ plots are within the critical bounds meaning that the model is stable, and therefore it can be used for policy formulation.

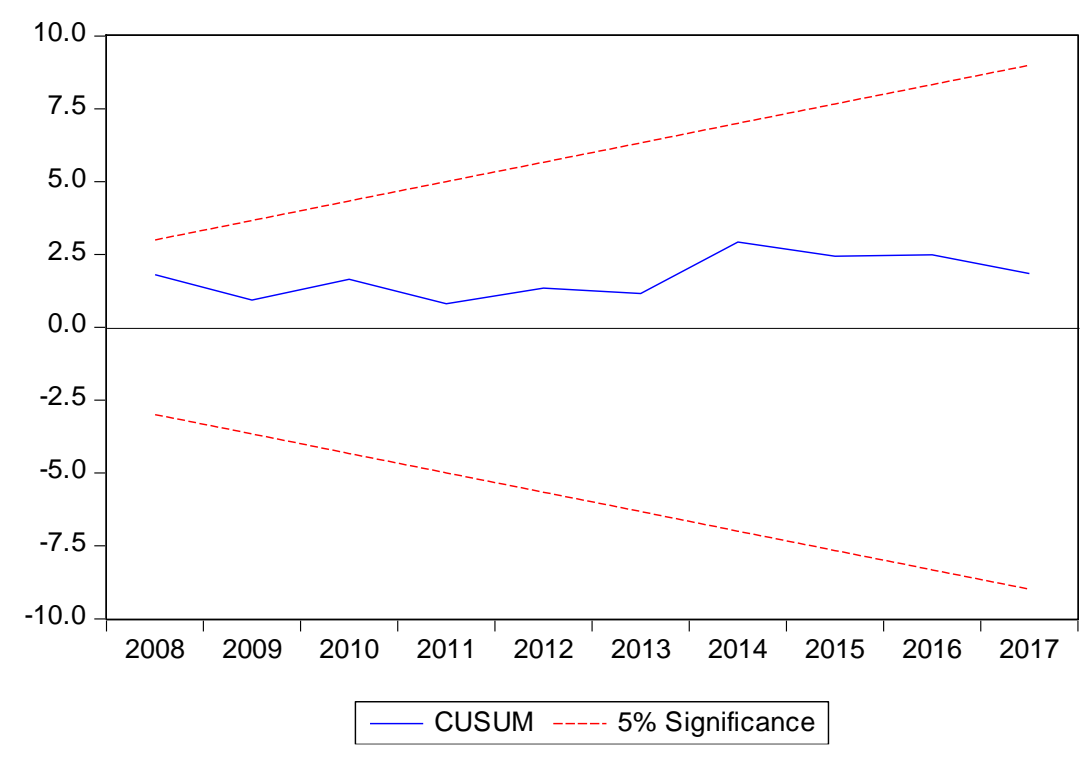

Fig. 2: Plot of CUSUM Test for Coefficients Stability of ARDL Long-Run

Source: Author's computation and Eviews 9.0 Output

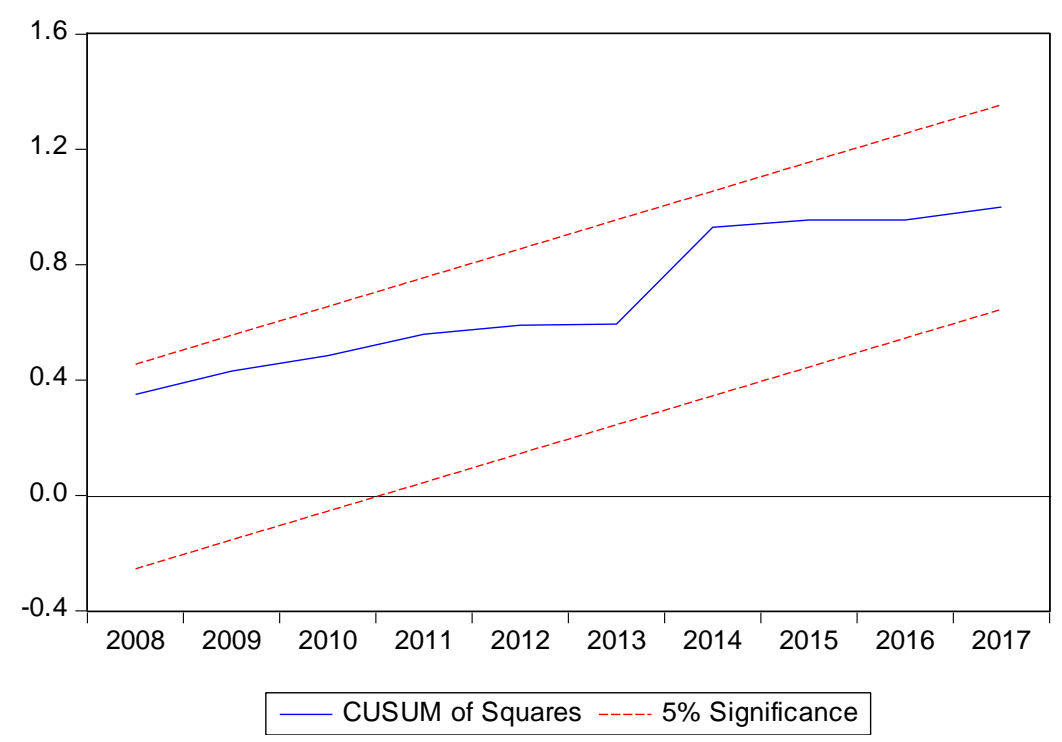

Fig.3: Plot of CUSUMSQ Test for Coefficients Stability of ARDL Long-Run

Source: Author's computation and Eviews 9.0 Output 


\subsection{Conclusion and Recommendations}

This paper assessed the impact of Exchange Rate Depreciation on Inflation in Nigeria. To achieve this, annual data on Inflation Rate (INF), Gross Domestic Product (GDP), General Government Expenditure (GGEXP), Broad Money (BM) and Exchange Rate (EXC) were collected from World Bank website (www.worldbank.org). The work covers the period of 1981-2017, using the Autoregressive Distributed Lag (ARDL) Bounds Test cointegration procedure. The results show that inflation rate in Nigeria is highly susceptible to lagged inflation rate, exchange rate, lagged exchange rate, lagged money supply, and lagged gross domestic product at 5\% level of significance. A long run relationship was also found to exist between inflation rate, gross domestic product and general government expenditure, indicating that the model has a self-adjusting mechanism for correcting any deviation of the variables from equilibrium. Therefore, this study concludes that exchange rate is an important tool to manage inflation in the country; thus, this paper recommends that policies that have direct influence on inflation as well as exchange rate policies that would checkmate inflation movement in the country, should be used by the Central Bank of Nigeria. Also, monetary growth and import management policies should be put in place to encourage domestic production of export commodities, which are currently short-supplied. In addition, policy makers should not rely on this instrument totally to control inflation, but should use it as a complement to other macro-economic policies.

\section{Reference}

Afolabi J.A, Oluyemi S.A. (1995). An Assessment of the Impact of Inflation on Financial Intermediation in Nigerian Banking Sector. NDIC Quarterly, 5 (1):29-48.

Emerenini, F. M., \& Eke, C. N. (2014). The Impact of Monetary Policy Rate on Inflation in Nigeria. Journal of Economics and sustainable Development, 5(28), 146-153.

Hunegnaw, F. B. (2012). An Empirical Investigation of Exchange Rate Pass through to Consumer Price in Ethiopia (1981-2013). Journal of Economics and Sustainable Development ISSN 2222-1700 (Paper) ISSN 2222-2855 (Online) Vol. 6, No.14,2015

Imimole B., and Enoma A., (2011). Exchange Rate Depreciation and Inflation in Nigeria (1986 -2008). Business and Economics Journal, Volume 2011: BEJ-28 Pp: 1 - 12.

Nwaru, N. M., \& Eke, C. N. (2017). An Econometric Analysis of the Effect of 
Exchange Rate on Inflation in Nigeria (1970-2014). International Journal of Innovative Finance and Economics Research 5(1):76-91, 2017

Onwioduokit EA, Adenuga AO, (2000). An Empirical Analysis of the Demand for Petroleum Products in Nigeria. CBN Economic and Financial Review, 38 (3).

Osakwe JO., (1983). Government Expenditure, Money Supply and Prices, 1970-1980. CBN: Economic and Financial Review, Vol. 21, No. 2, June.

Ouattara, B., (2004). "Foreign Aid and Fiscal Policy in Senegal." Mimeo University of Manchester.

Pesaran, M.H., Shin, Y., Smith, R.J., (2001). Bounds Testing Approaches to the Analysis of Level Relationships. Journal of Applied Econometrics, 16, 289-326.

Ude, D. K., \& Anochie, U. C. (2014). Exchange Rate Pass-Through, Monetary policy and Price Stability in Nigeria. International Journal of Science and Research, 3(9), 1082-1087. 